\title{
Influence of human activities on the soils of Debrecen, Hungary ${ }^{1}$
}

\author{
University of Debrecen, Institute of Geography, Department of Landscape Protection and Environmental Geography \\ Egyetem square 1, 4032 Debrecen, Hungary
}

\begin{abstract}
Soil profiles of the city centre of Debrecen were investigated in order to examine their properties and investigate the vertical distribution of heavy metals as a measure the anthropogenic activity. During the laboratory work the basic soil features were identified (texture, artefact content, $\mathrm{pH}, \mathrm{CaCO}_{3}$, and amounts of organic matter). Furthermore, contents of $\mathrm{Pb}, \mathrm{Zn}, \mathrm{Cu}$ and $\mathrm{Co}$ in the soils were measured. Most of the metals showed a strong positive correlation with the humus content and the silt fraction. The soils of the city centre are exposed to a significant anthropogenic effect, therefore the original soil morphologies are usually difficult to identify. The soil profiles are greatly disturbed, which is traceable in the vertical distribution of certain soil features and metal contents.
\end{abstract}

Keywords: urban soils, Debrecen, anthropogenic effect, artefact content, metal content

\section{INTRODUCTION}

The increasing expansion of settlements invitably leads to the modification and damage of the environment. During the constructions, it is often necessary to do various landscape works, which may completely change the original morphology of the surface. In the course of landscaping, the soils can suffer great damages as well. Due to the banking up, the increasing amount of artificial objects and the development of a whole new cultural layer have to be expected. Furthermore, due to the levelling and carrying away of the higher areas, deeper parts of the soil are exposed, which are therefore directly affected by the anthropogenic effects. Previously during the investigation of the urban soils of Debrecen, we studied urban development and the construction of transportation routes mostly (Szabó 1998). In the recent years, more papers were published on the investigation of urban soils of Hungary - most of these deal with the heavy metal content of the urban soils the soil features modified by anthropogenic effect and the classification of urban soils(Kovács and Nyári 1984; Szegedi 1999; Puskás 2008; Bidló 2012; Horváth et al. 2013; Snador et al. 2013).

The objective of the present paper was to examine and interpret the features of the urban soils of Debrecen and investigate the vertical distribution of heavy metals in order to measure the ratio of anthropogenic effects.

${ }^{1}$ Article presented on SUITMA 7 conference, 16-20 September 2013, Toruń, Poland.

\section{MATERIALS AND METHODS}

In August 2012, samples from 11 soil profiles in the city centre of Debrecen were collected. In total, 67 samples were analysed. We attempted to select the profiles in a way that they would cover the study area proportionally (Fig. 1). The depth of the certain profiles varied from 1 to $2 \mathrm{~m}$. At most of the profiles (8) an artificial, hard technical layer can be identified (pavement, road surface), which can be up to $40 \mathrm{~cm}$ thick.

The examination of the samples took place in the soil laboratory of the Department of Landscape Protection and Environmental Geography, University of Debrecen. The soil samples were dried at $40^{\circ} \mathrm{C}$, then eliminated the various material of anthropogenic origin, which are referred to as the artefact content of the samples. Their amount in percentage of the weight of the original soil samples were indicated. For the separation of the rough fraction a $2 \mathrm{~mm}$ sieve was used. The earthy material (fraction $<2 \mathrm{~mm}$ ) was used during the further investigations.

The particle size distribution of the soil was identified by sieving in the case of the fraction $>0.2 \mathrm{~mm}$, and by decantation in the case of the fraction $<0.2 \mathrm{~mm}$. The $\mathrm{pH}$ value of soils was measured potentiometrically in a water and $\mathrm{KCl}$ with a ratio of $1: 2.5$. The $\mathrm{CaCO}_{3}$ content of the soil was identified using Scheibler calcimeter, and the organic material content was identified by the Tyurin method. In order to identify the heavy metal content, $5 \mathrm{ml}$ concentrated nitric acid and $2 \mathrm{ml}$ hydrogen peroxide were added for $2 \mathrm{~g}$ soil sample, then the samples were destructed at $130^{\circ} \mathrm{C}$ for one and a half hour. The $\mathrm{Co}, \mathrm{Zn}, \mathrm{Pb}$, and $\mathrm{Cu}$ con- 
FIGURE 1. The location of the soil profiles in the city centre of Debrecen
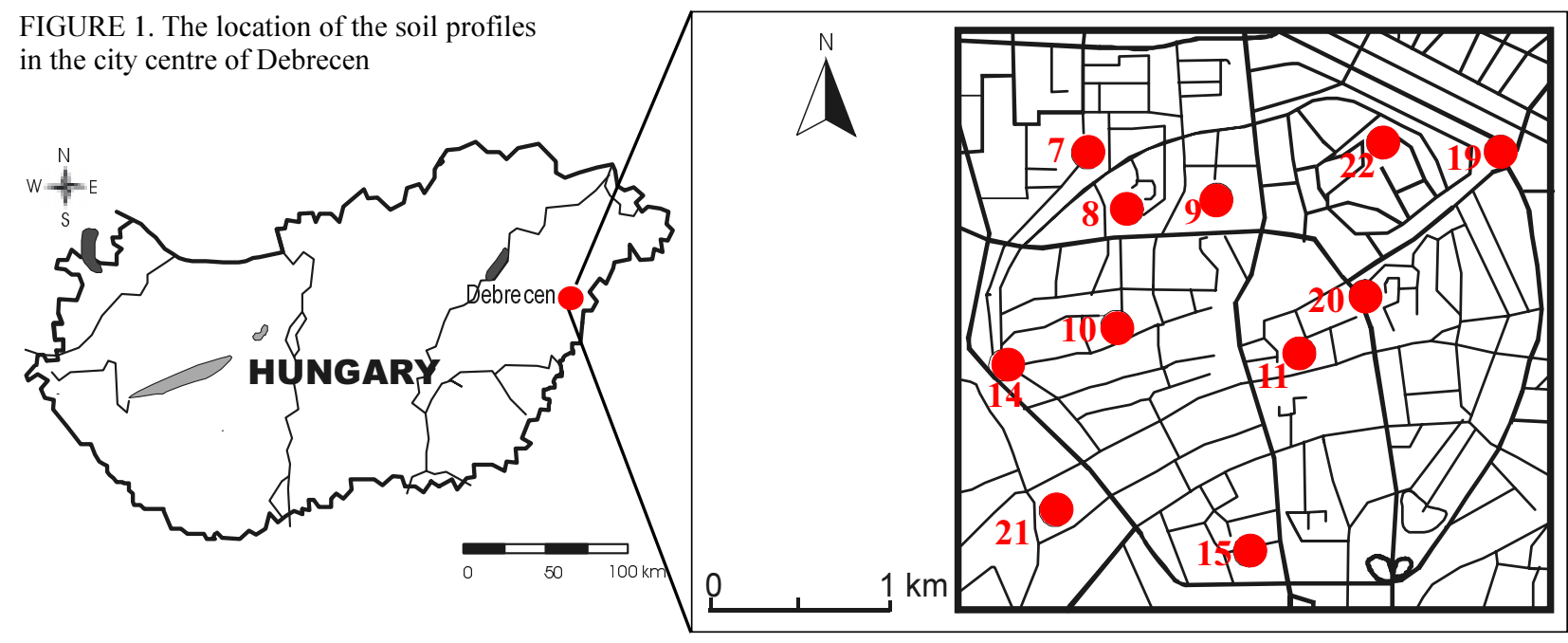

tent of the samples were identified with Agilent MPAES 4100.

The correlation analyses were made with SPSS for Windows Release 8.0 software and the figures were made using $\mathrm{C} 21.7$ software.

\section{STUDY AREA}

With a population of 200.000 , Debrecen is located in the eastern part of Hungary on the border of the Hajdúság and the Nyírség landscapes. The landscape border can be found in the western part of the city. The various landscape features affect the soil conditions as well, considering that in the sandy areas of the Nyírség mostly Arenosol can be found. On the loess plains of the Hajdúság, the most frequent soil types are Chernozems and Phaeozems. The lower areas of the Hajdúság are often exposed to inland water during the rainy season (Martonné 2008).

Debrecen has already been populated for the Ancient Ages. The present city centre used to be four separated villages, but they almost completely disappeared. The hub of the city centre was a wet dune between depressions where planks were used for making the traffic possible. The area has been filled up through the centuries, and today the original soil surface can be found only at the depth of 2-3 meters (Csorba 2008). The areas circumjacent the city centre are higher, therefore here the culture layer is usually thinner.

Debrecen is no a highly polluted city, however, in the city centre the pollution originated from the transportation is a major issue. The industrial companies - as the main emitters of the polluting agents - are located in four industrial parks.

\section{RESULTS AND DISCUSSION}

\section{Basic soil properties}

In most of examined profiles the sand fraction is dominant (more than $80 \%$ in majority of profiles). The profiles 7 and 8 are the exceptions since in this case the rate of sand fraction is between 55 and $76 \%$. In majority of profiles the content of clay is below $10 \%$, except for profile 7 where the rate of the clay fraction was measured more than $10 \%$ in several layers of the profile, and in cases of profiles 8, 14 and 15, where the clay content was above the $10 \%$ only in the subsoil (Table 1).

The $\mathrm{pH}$ of the soil samples varied from 7.9 to 8.9. Most of them was mildly alkaline, some of them alkaline. In the majority of profiles $(7,8,10,11,15$, $19,21)$ we found a connection between the $\mathrm{pH}$ and the $\mathrm{CaCO}_{3}$ content of the soil, as long as the higher $\mathrm{pH}$ values of a given profile are generally attributed with higher calcium content (Table 1).

Majority of the collected samples can be classified as moderately calciferous (3-10\% of calcium carbonate) (Table 1). The average calcium carbonate content in profiles exceeded $10 \%$ in profile 7 only, therefore that is ranked among the strongly calciferous soils (IUSS Working Group WRB 2007). The calcium carbonate content in the profile 8,10,11, 14 and 21 shows an increasing tendency with depth, whereas in the profile 9, 19 and 20 the calcium carbonate content shows a decreasing tendency with depth (Fig. 2). The soils of Debrecen naturally contain calcium carbonate, therefore it is appearance may not be an effect of human activity, however we found that there was higher calcium carbonate content in profiles with higher artificial content as well. In these cases, we can assume anthropogenic effect. 
TABLE 1. Properties of the soils studied

\begin{tabular}{|c|c|c|c|c|c|c|c|c|c|c|c|c|c|}
\hline \multirow[t]{2}{*}{ Profile } & \multirow[t]{2}{*}{$\begin{array}{l}\text { Depth } \\
\text { (cm) }\end{array}$} & \multicolumn{3}{|c|}{$\begin{array}{l}\text { Percentage of fractions } \\
(\mathrm{mm})\end{array}$} & \multirow{2}{*}{$\begin{array}{l}\begin{array}{l}\text { Content } \\
\text { of artefact }\end{array} \\
(\%)\end{array}$} & \multirow[t]{2}{*}{$\mathrm{pH} \mathrm{H}_{2} \mathrm{O}$} & \multirow[t]{2}{*}{$\mathrm{pH} \mathrm{KCl}$} & \multirow{2}{*}{$\begin{array}{l}\mathrm{CaCO}_{3} \\
(\%)\end{array}$} & \multirow{2}{*}{$\begin{array}{l}\begin{array}{l}\text { Organic } \\
\text { matter }\end{array} \\
(\%)\end{array}$} & Cobalt & \multicolumn{2}{|c|}{ Copper Lead } & \multirow[t]{2}{*}{ Zinc } \\
\hline & & $2-0.02$ & $0.02-0.002$ & $<0.002$ & & & & & & $\left(\mathrm{mg} \cdot \mathrm{kg}^{-}\right.$ & & & \\
\hline Profile & $20-40$ & 71.8 & 19.8 & 8.4 & 16.38 & 8.25 & 8.14 & 11.36 & 1.63 & 3.9 & 17.1 & 43.5 & 45.5 \\
\hline 7 & $40-60$ & 67.1 & 21 & 11.9 & 7.24 & 8.31 & 8.4 & 9.91 & 1.26 & 4.2 & 17 & 47.5 & 42 \\
\hline & $60-80$ & 76.3 & 17.5 & 6.2 & 8.21 & 8.39 & 8.42 & 8.36 & 1.31 & 4 & 18.8 & 40 & 43.5 \\
\hline & $80-100$ & 71.6 & 21 & 7.4 & 4.35 & 8.38 & 8.35 & 9.87 & 1.29 & 4.3 & 18.2 & 49.5 & 46.5 \\
\hline & $100-120$ & 65.9 & 21.3 & 12.8 & 9.91 & 8.25 & 8.34 & 9.21 & 1.27 & 4.2 & 15.2 & 39 & 41.5 \\
\hline & $120-140$ & 74 & 18.7 & 7.3 & 4.21 & 8.4 & 8.4 & 10.85 & 1.31 & 3.8 & 15.8 & 41.5 & 38 \\
\hline & $140-160$ & 70.2 & 22.3 & 7.5 & 4.48 & 8.46 & 8.5 & 11.01 & 0.79 & 3.5 & 14.9 & 37.5 & 39.5 \\
\hline & $160-180$ & 58.3 & 26.5 & 15.2 & 3.64 & 8.46 & 8.45 & 12.34 & 0.66 & 4.4 & 13.1 & 32.5 & 34.5 \\
\hline & $180-200$ & 69.4 & 23.1 & 7.5 & 3.29 & 8.49 & 8.45 & 12.37 & 0.74 & 3.6 & 13.6 & 28.5 & 36.5 \\
\hline Profile & $0-20$ & 72.5 & 18.5 & 9 & 3.28 & 8.1 & 7.96 & 5.96 & 1.8 & 5.1 & 18.3 & 31 & 47 \\
\hline 8 & $20-40$ & 73 & 19 & 8 & 3.36 & 8.06 & 7.97 & 5.85 & 1.73 & 5.9 & 18.5 & 35 & 45 \\
\hline & $40-60$ & 66.2 & 27.1 & 6.7 & 2.64 & 8.4 & 8.27 & 10.28 & 1.26 & 4 & 19.7 & 34 & 47 \\
\hline & $60-80$ & 58.3 & 31.8 & 9.9 & 1.16 & 8.56 & 8.4 & 11.82 & 0.69 & 3 & 18.8 & 30 & 45.5 \\
\hline & $80-100$ & 57.6 & 30.6 & 11.8 & 0.21 & 8.71 & 8.47 & 9.92 & 1.19 & 3.3 & 17.1 & 31 & 45.5 \\
\hline & $100-120$ & 55.2 & 29.7 & 15.1 & 0.15 & 8.93 & 8.59 & 12.31 & 0.64 & 3.3 & 18.9 & 32.5 & 46.5 \\
\hline Profile & $0-20$ & 83.2 & 10.7 & 6.1 & 8.46 & 8.47 & 8.33 & 6.65 & 1.12 & 6.2 & 16.8 & 39.5 & 36 \\
\hline 9 & $20-40$ & 85.4 & 8.6 & 6 & 6.98 & 8.38 & 8.27 & 7.45 & 0.8 & 5.9 & 14.5 & 35 & 35.5 \\
\hline & $40-60$ & 87.7 & 7.1 & 5.2 & 8.16 & 8.35 & 8.29 & 6.03 & 0.54 & 7.1 & 10 & 22 & 27 \\
\hline & $60-80$ & 87.5 & 6.6 & 5.9 & 7.61 & 8.35 & 8.26 & 6.16 & 0.78 & 6.7 & 11.6 & 39 & 30 \\
\hline & 80-100 & 86 & 8.4 & 5.6 & 5.08 & 8.3 & 8.24 & 5.76 & 0.67 & 6.6 & 11.5 & 24.5 & 30 \\
\hline & $100-120$ & 89.2 & 6.5 & 4.3 & 5.73 & 8.05 & 8.08 & 5.64 & 0.67 & 6.1 & 14.2 & 28.5 & 35 \\
\hline Profile & $40-60$ & 84.3 & 9.7 & 6 & 4.99 & 8.78 & 8.35 & 6.38 & 1.32 & 5.4 & 20.5 & 79 & 36.5 \\
\hline & $60-80$ & 78.5 & 14 & 7.5 & 3.58 & 8.63 & 8.31 & 8.01 & 1.2 & 4.9 & 21.3 & 63 & 33.5 \\
\hline & $80-100$ & 86 & 9.6 & 4.4 & 0.21 & 8.52 & 8.32 & 6.18 & 1.17 & 6 & 10.9 & 43 & 26.5 \\
\hline & $100-120$ & 82.4 & 12.5 & 5.1 & 2.62 & 8.57 & 8.25 & 7.22 & 1.88 & 5.4 & 16.1 & 42.5 & 36 \\
\hline & $120-130$ & 73.3 & 17.9 & 8.8 & 2.16 & 8.78 & 8.26 & 10.4 & 2 & 4.2 & 30.1 & 33.5 & 49.5 \\
\hline Profile & $0-20$ & 85 & 12.5 & 2.5 & 7.53 & 8.04 & 8 & 5.41 & 1.87 & 5.3 & 21.2 & 53.5 & 116 \\
\hline 11 & $20-40$ & 81.7 & 14.4 & 3.9 & 6.79 & 8.23 & 8.13 & 6.24 & 1.48 & 5.2 & 19 & 44.5 & 86.5 \\
\hline & $40-60$ & 77.5 & 15.1 & 7.4 & 6.61 & 8.31 & 8.21 & 5.7 & 1.03 & 5.5 & 21.5 & 38.5 & 70.5 \\
\hline & $60-80$ & 78.7 & 13 & 8.3 & 6.91 & 8.42 & 8.3 & 6.04 & 1.18 & 6.1 & 15.5 & 32.5 & 51 \\
\hline & $80-96$ & 84.4 & 11.7 & 3.9 & 16.16 & 8.5 & 8.33 & 10.85 & 1.33 & 4.6 & 29.6 & 127 & 108.5 \\
\hline Profile & $20-40$ & 94.2 & 3.8 & 2 & 14.56 & 8.93 & 8.4 & 2.54 & 0.32 & 7.4 & 6.3 & 10.5 & 20 \\
\hline 14 & $40-60$ & 93.4 & 2.6 & 4 & 0.84 & 8.64 & 8.28 & 3.22 & 0.7 & 7.3 & 7.8 & 10 & 21 \\
\hline & $60-80$ & 79.5 & 13.8 & 6.7 & 3.81 & 8.31 & 7.97 & 8.06 & 2.09 & 4.4 & 34.1 & 79.5 & 69 \\
\hline & $80-100$ & 89.3 & 9 & 1.7 & 1.20 & 8.09 & 7.84 & 5.33 & 2.44 & 5.8 & 23.8 & 35.5 & 60.5 \\
\hline & $100-120$ & 81.4 & 16.9 & 1.7 & 0.20 & 8.04 & 7.76 & 7.71 & 2.82 & 3.9 & 28.7 & 64 & 73 \\
\hline & $120-130$ & 53.9 & 29.1 & 17 & 0.11 & 8.17 & 7.84 & 10.61 & 2.75 & 3.6 & 29.9 & 104 & 73.5 \\
\hline Profile & $20-40$ & 94.9 & 3.6 & 1.5 & 13.12 & 8.38 & 8.31 & 3.56 & 0.47 & 7.4 & 5.9 & 32.5 & 29.5 \\
\hline 15 & $40-60$ & 81.7 & 11.3 & 7 & 8.98 & 8.43 & 8.18 & 9.28 & 0.96 & 5 & 24.2 & 44 & 53.5 \\
\hline & $60-80$ & 68.5 & 20.7 & 10.8 & 9.49 & 8.54 & 8.17 & 11.9 & 1.46 & 4.5 & 21.9 & 42.5 & 100 \\
\hline & $80-100$ & 71.5 & 19.5 & 9 & 4.21 & 8.51 & 8.2 & 8.89 & 1.41 & 3.9 & 24.4 & 72.5 & 62.5 \\
\hline Profile & $40-60$ & 85.9 & 8.7 & 5.4 & 15.87 & 8.76 & 8.38 & 7.2 & 0.54 & 6.8 & 13.5 & 41.5 & 45.5 \\
\hline 19 & $60-80$ & 85.4 & 8.6 & 6 & 14.95 & 8.6 & 8.26 & 5.1 & 0.92 & 6 & 15 & 49.5 & 46.5 \\
\hline & $80-100$ & 88.2 & 6.6 & 5.2 & 6.00 & 8.45 & 8.3 & 5.76 & 0.35 & 6.2 & 12.3 & 33.5 & 38.5 \\
\hline & $100-120$ & 90.9 & 4.4 & 4.7 & 1.32 & 8.31 & 8.28 & 3.87 & 0.28 & 7.2 & 9.2 & 16 & 28.5 \\
\hline & $120-140$ & 90.8 & 5.8 & 3.4 & 1.95 & 8.32 & 8.29 & 2.53 & 0.27 & 6.8 & 8.7 & 15 & 29 \\
\hline & $140-160$ & 91 & 4.3 & 4.7 & 1.35 & 8.33 & 8.3 & 4.40 & 0.25 & 7.8 & 7.2 & 12 & 21.5 \\
\hline & $160-180$ & 93.4 & 2.8 & 3.8 & 0.84 & 8.55 & 8.36 & 4.88 & 0.15 & 7 & 9.7 & 14.5 & 28 \\
\hline Profile & $15-20$ & 91 & 5 & 4 & 6.55 & 8.17 & 8.28 & 4.51 & 0.82 & 7 & 18.4 & 29.5 & 48.5 \\
\hline 20 & $20-40$ & 85.7 & 9.2 & 5.1 & 7.36 & 8.23 & 8.18 & 5.87 & 0.79 & 5.2 & 49.7 & 43.5 & 62 \\
\hline & $40-60$ & 88.3 & 7.5 & 4.2 & 3.86 & 8.09 & 8.11 & 4.87 & 0.75 & 6.6 & 80.5 & 71 & 57 \\
\hline & $60-80$ & 89.3 & 8.4 & 2.3 & 2.07 & 8.04 & 8.02 & 5.48 & 0.63 & 6.4 & 82.1 & 40.5 & 60.5 \\
\hline & $80-100$ & 82.2 & 11.9 & 5.9 & 2.1 & 7.99 & 8 & 5.06 & 1.32 & 5.9 & 29.8 & 223 & 65 \\
\hline & $100-120$ & 86.2 & 11.1 & 2.7 & 1.33 & 7.95 & 7.89 & 3.92 & 1.52 & 5.8 & 27.3 & 60.5 & 67 \\
\hline & $120-130$ & 82.6 & 10.8 & 6.6 & 0.09 & 7.88 & 7.8 & 4.51 & 1.56 & 6 & 20 & 31.5 & 64.5 \\
\hline Profile & $20-40$ & 86.3 & 11.2 & 2.5 & 8.72 & 7.92 & 7.82 & 5.5 & 2.04 & 4.7 & 42.6 & 118.5 & 127.5 \\
\hline 21 & $40-60$ & 82.8 & 14.4 & 2.8 & 8.35 & 8.14 & 8.01 & 8.45 & 2.09 & 4.5 & 35.1 & 65.5 & 94.5 \\
\hline & $60-80$ & 78.6 & 17.5 & 3.9 & 9.08 & 8.28 & 8.09 & 11.77 & 2.04 & 3.8 & 39.2 & 73 & 102 \\
\hline & 80-100 & 66.6 & 22.2 & 11.2 & 3.96 & 8.3 & 8.09 & 10.96 & 1.85 & 4.5 & 36.5 & 142 & 105 \\
\hline & $100-115$ & 60.8 & 29.2 & 10 & 0.57 & 8.36 & 8 & 12.26 & 2.84 & 2.9 & 41.9 & 98.5 & 99 \\
\hline
\end{tabular}


continuation of Table 1

\begin{tabular}{|c|c|c|c|c|c|c|c|c|c|c|c|c|c|}
\hline \multirow[t]{2}{*}{ Profile } & \multirow[t]{2}{*}{$\begin{array}{l}\text { Depth } \\
(\mathrm{cm})\end{array}$} & \multicolumn{3}{|c|}{$\begin{array}{l}\text { Percentage of fractions } \\
(\mathrm{mm})\end{array}$} & \multirow{2}{*}{$\begin{array}{l}\begin{array}{l}\text { Content } \\
\text { of artefact }\end{array} \\
(\%)\end{array}$} & \multirow[t]{2}{*}{$\mathrm{pH} \mathrm{H} \mathrm{H}_{2} \mathrm{O}$} & \multirow[t]{2}{*}{$\mathrm{pH} \mathrm{KCl}$} & \multirow{2}{*}{$\begin{array}{l}\mathrm{CaCO}_{3} \\
(\%)\end{array}$} & $\begin{array}{l}\text { Organic } \\
\text { matter }\end{array}$ & Cobalt & \multicolumn{2}{|c|}{ Copper Lead } & \multirow[t]{2}{*}{ Zinc } \\
\hline & & $2-0.02$ & $0.02-0.002$ & $<0.002$ & & & & & $(\%)$ & (mg.kg & & & \\
\hline Profile & $20-40$ & 93.8 & 4.9 & 1.3 & 3.92 & 7.96 & 7.82 & 5.19 & 1.05 & 6.4 & 16.1 & 31.5 & 46 \\
\hline 22 & $40-60$ & 87.5 & 7.7 & 4.8 & 3.74 & 8.01 & 7.88 & 5.56 & 0.94 & 5.6 & 16.9 & 34.5 & 53 \\
\hline & $60-80$ & 84.7 & 9.4 & 5.9 & 3.3 & 7.99 & 7.96 & 5.79 & 1.09 & 5.4 & 20.1 & 42 & 71 \\
\hline & $80-100$ & 86.3 & 8.8 & 4.9 & 3.93 & 8.03 & 7.88 & 6.03 & 0.99 & 6.2 & 15.7 & 90 & 48 \\
\hline & $100-120$ & 87.9 & 7.9 & 4.2 & 5.05 & 8.02 & 7.9 & 4.84 & 1.06 & 5.8 & 16.6 & 55.5 & 53 \\
\hline & $120-140$ & 89.6 & 6.2 & 4.2 & 2.18 & 8 & 7.95 & 5.33 & 0.67 & 6.9 & 9.7 & 19 & 35.5 \\
\hline & $140-160$ & 90.6 & 5.7 & 3.7 & 2.56 & 7.99 & 7.91 & 2.83 & 0.61 & 7.8 & 7.7 & 14 & 28.5 \\
\hline
\end{tabular}

The organic matter content is less than $2 \%$ in every case where hard artificial covering layer cannot be found $(7,8,9,11)$. However, the decreasing tendency of the humus content towards the deeper layers can be identified only at the profile 7 . In the rest of the profiles we can find layers with higher organic matter contents in deeper layers, which are probably caused by the disruption. The distribution of organic matter in soils containing hard rock (profiles 14, 15, $19,20,21,22)$ is irregular (Table 1).

Profile 19 had the lowest organic matter contents $(0.15-0.92 \%)$ (Table 1). The layer situated directly under the asphalt which was used for the base of the road, has a low organic matter content $(0.54 \%)$. The next level supposedly constituted the original surface layer $(0.92 \%)$, because the organic matter shows regular decrease towards the deeper layers.

\section{Contents of artefacts}

One of the most conspicuous manifestation of the anthropogenic effect is the appearance of the artefact content in the soil profiles (Fig. 3). The average artefact content of the investigated 11 profiles is 5.3\% which is classified into the "common" category (5$15 \%$ ) according to the categorization of the FAO (IUSS Working Group WRB 2007). The most frequent anthropogenic materials are the construction and destruction rubbles which often have high calcium carbonate content. Moreover, glass and metal can be found in them as well. There are profiles (no. 14 and 19) where the calcium carbonate content of certain layers is around $10 \%$ or higher - these profiles generally have a $20-40 \mathrm{~cm}$ thick hard artificial layer from the surface (Fig. 2). The great disruption of the layers situated directly underneath them is due to the construction of pavement and roads and the banking up of their track. The profiles 8 and 9 which were less affected by the road constructions, do not have such technical layer and contain less construction rubbles.

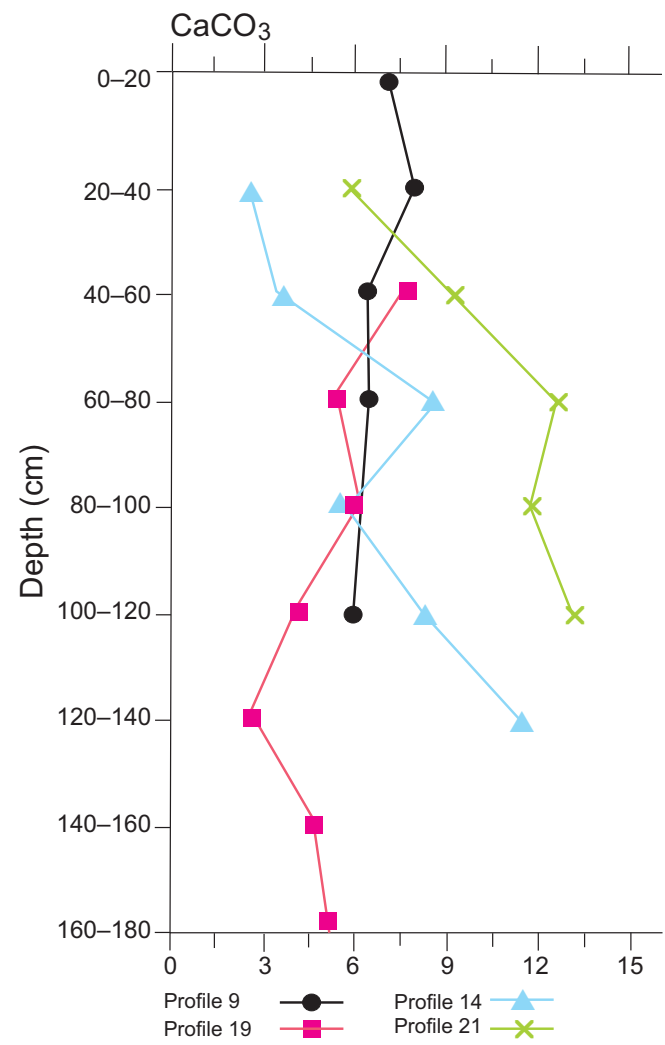

FIGURE 2. The distribution of calcium carbonate content (\%) in profile $9,19,14,21$

The amount of the anthropogenic materials was the highest in the profile 7 and 11 (Table 1). High quantities of construction rubbles are found in the surface layer of the profile $7(16.38 \%)$ and their amounts decrease downwards. However, that tendency is not linear: we can find $9 \%$ of artefacts at the depth of $1 \mathrm{~m}$, the further layers of the profile have on average around $5 \%$ of artificial constituents (Fig. 3). In all horizons of the profile 11 we identified values above average $(5,3 \%)$, with the difference that the lowest layer of the profile contains the highest amounts of artificial material $(16,16 \%)$. 


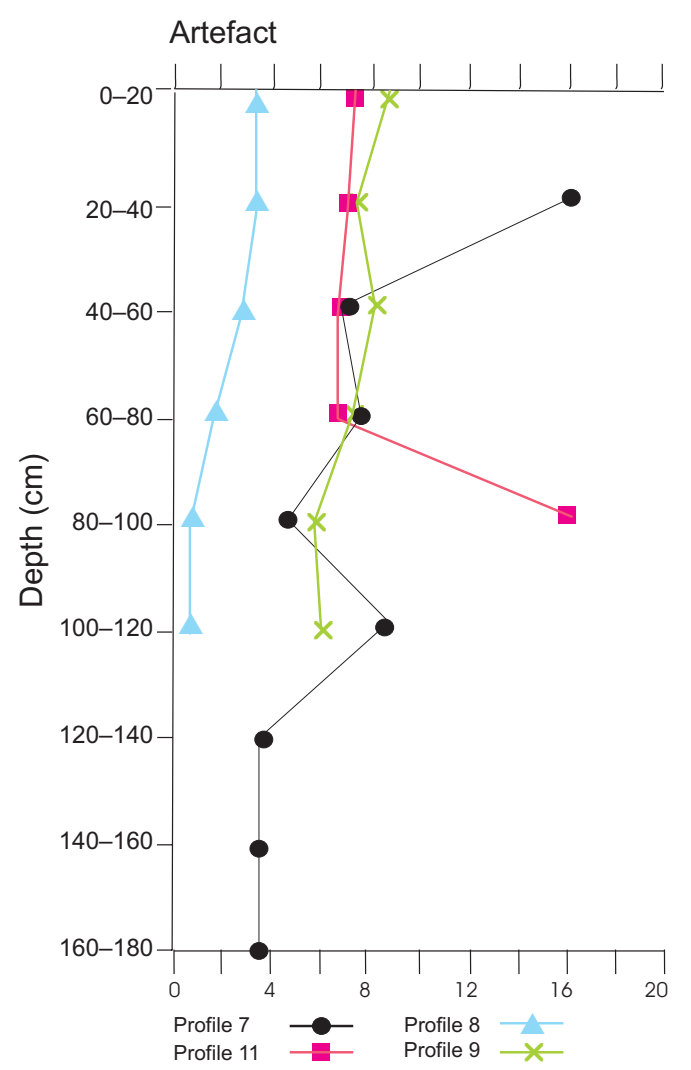

FIGURE 3. The distribution of artefact content (\%) in profile 8 , $9,7,11$

\section{Contents and distribution of heavy metals}

The heavy metal adsorption capacity of the soils of Debrecen is usually small, thanks to the relatively high ratio of the rough grain fraction and low humus content (Table 1). The most important source of heavy metal pollution is unambiguously the transportation, however, there are some industrial facilities in the city, the operation of which is accompanied by heavy metal emission. Such facility are, for instance, the thermal power plant, the MÁV service station or the TEVA pharmaceuticals. Concentrations of Co and $\mathrm{Zn}$ were below the limits detailed in the 6/2009 (IV. 14.) of the KvVM-EüM-FVM's (Hungarian Ministries of Environment, Healthcare and Agriculture) joint decree, which is presently in force in Hungary. However, in the case of copper and lead we measured concentrations which exceeded the limits, but extremely high values were not found.

The distribution of heavy metals in the profiles is affected by more factors. One of them is the source of the given heavy metal, which can be of anthropogenic or lithogenic origin. Naturally, these categories are not exclusive, but the character of the distribution can indicate the dominant source. According to the papers dealing with urban soils, lead, copper and zinc usually are of an anthropogenic origin, while cobalt has primarily a lithogenic origin in the urban soils (Imperato et al. 2003; Lark and Scheib 2013; Li et al. 2011; Puskás and Farsang 2006; Shi et al. 2008; Szalai and Németh 2008; Charzyński and Hulisz 2013).

The distribution of heavy metals in soil profiles is also affected by the disruption of the profile, since the original distribution is completely reorganized during the disruption. In the undisrupted profiles the heavy metals of anthropogenic origin are generally accumulated in the upper layer of the soil and their concentration is decreasing downwards, whereas the heavy metals with lithogenic origin are often accumulated in the deeper layers (Puskás and Farsang 2006; Shi et al. 2008).

The vertical distribution of the heavy metals can be affected by the artefact content, as long as the artificial materials may contain metals (Howard and Olszewska 2011). This can be seen in profile 11, where artefact content was high in the deepest layer of the profile and the lead, zinc and copper content reached their maximum in this layer (Fig. 4). In the case of lead, the measured value exceeded the Hungarian limit (100 $\mathrm{mg} \cdot \mathrm{kg}^{-1}$, according to the $6 / 2009$ joint decree).
FIGURE 4.

The vertical distribution of organic matter

(\%), artefact

(\%) and heavy metal content $\left(\mathrm{mg} \cdot \mathrm{kg}^{-1}\right)$

in profile 11

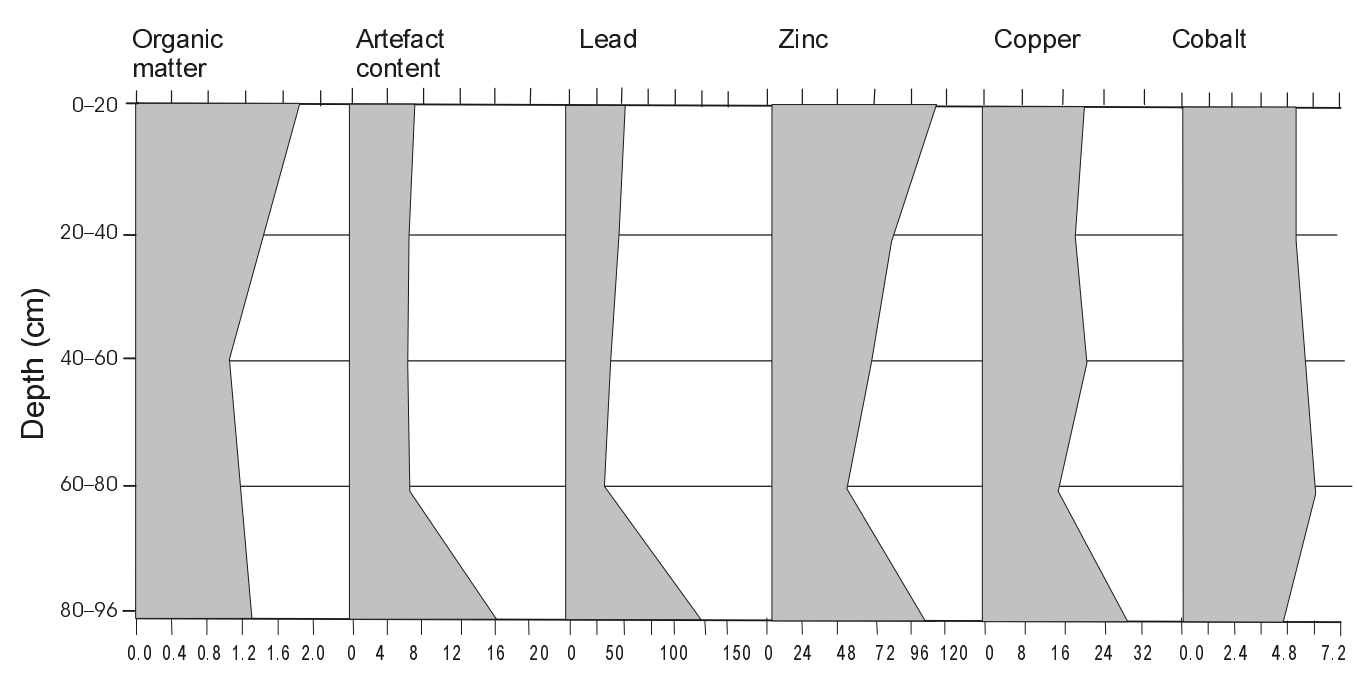




\section{Degree of the disruption of soils}

In the cities, the soils are often disrupted, particularly when the history of the settlement is dated back to centuries before. This is the case in the city centre of Debrecen, since all of the investigated profiles were disrupted, which can be traced by the heavy metal distribution in the profiles studied. This distribution is also affected by the humus content and the particle size distribution, because of the greater adsorption capacity of the humus materials and the smaller grain fractions. This finding was underpinned by the Spearman's correlation tests as well. The strongest positive correlation was found between the humus content and the copper, zinc and lead content of the soil (Table 2) which indicates the heavy metal absorption affinity of the humus materials (Kovács and Nyári 1984; Hargitai 1989; Szabó and Posta 2008; Szabó et al. 2008). Usually negative correlation is shown between the ratio of the sand fraction and the concentration of the investigated heavy metals (Table 2). Based on the correlation coefficients, we established that the silt fraction has the highest adsorption capacity, which shows a strong positive correlation with the heavy metal content with the exception of cobalt. In our former study we have realized a stronger correlation between the silt fraction and heavy metals (Szabó 2000).

Based on heavy metal distribution, there were differences between the investigated profiles regarding the extent of disruption. For instance, in the case of profile 19, we only found indications of disruption in the upper $100 \mathrm{~cm}$ layer of the profile, whereas the layers deeper than $100 \mathrm{~cm}$ appeared to be undisrupted (Fig. 5). The rates of humus and the artificial material content were also the highest in the upper 100 $\mathrm{cm}$ layer, and the metals (lead, zinc, copper) origina-
TABLE 2. Spearmen's correlation coefficients

\begin{tabular}{lcccc}
\hline Soil featurelMetal & Cobalt & Copper & Lead & Zinc \\
\hline Humus content & $-0.66^{* *}$ & $0.71^{* *}$ & $0.68^{* *}$ & $0.72^{* *}$ \\
Sand fraction & $0.66^{* *}$ & $-0.26^{*}$ & -0.21 & -0.18 \\
Silt fraction & $-0.9^{* *}$ & $0.57^{* *}$ & $0.45^{* *}$ & $0.52^{* *}$ \\
Clay fraction & $-0.54^{* *}$ & 0.16 & 0.10 & 0.06 \\
\hline
\end{tabular}

Explanation: $(* * \mathrm{p}<0,01 ; * \mathrm{p}<0,05)$

ting from anthropogenic sources were also concentrated in this layer (Table 1). The vertical distribution of the cobalt was generally even in the whole profile.

In the case of profile 14 the surface of the original soil was covered with a layer which was rich in artificial materials and debris. This layer contained low amounts of organic matter and hardly contained $\mathrm{Cu}$, $\mathrm{Pb}$, and $\mathrm{Zn}$ heavy metals, with the exception of cobalt. The original soil surface begins at appr. $60 \mathrm{~cm}$ depth. Here the humus content was significantly higher and the lead, copper and zinc content were also increased relatively to the rates measured in the upper layer. In this case, the whole profile is disrupted, since the humus content has an irregular pattern, as it was increasing towards the deeper layers. At the same time the contents of metals (lead, zinc, copper) also increased downwards (Fig. 6).

Profile 21 is located in a vegetable garden on the southwestern part of the study area, on the border zone between Nyírség and Hajdúság. The transition towards Hajdúság is indicated by the higher humus content in the profile, and different particle size distribution than in soils of Nyírség. The traces of disruption can be observed in the whole profile, however, the content of the metals - with the exception of lead - shows a surprisingly even vertical distribution (Fig. 7). Moreover, the distribution of organic matter is also even, which indicates that homogenous humus

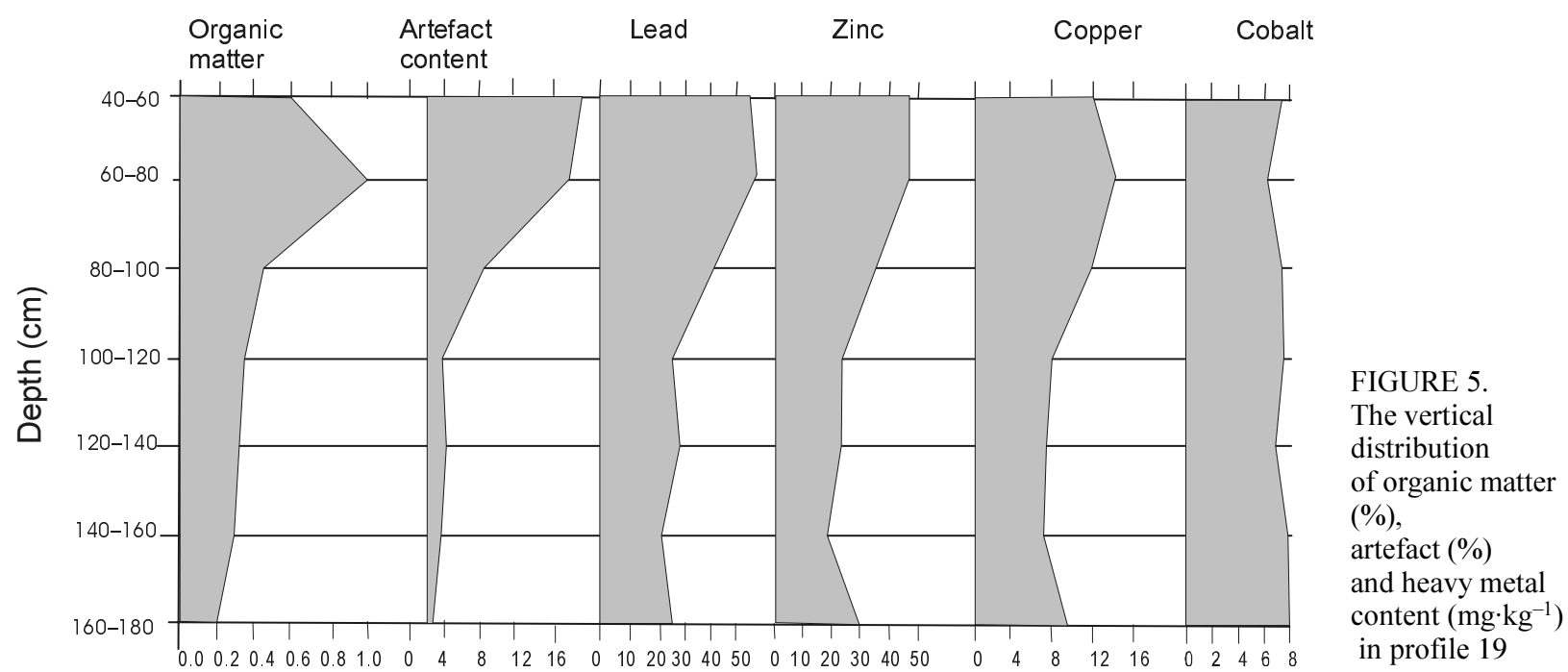




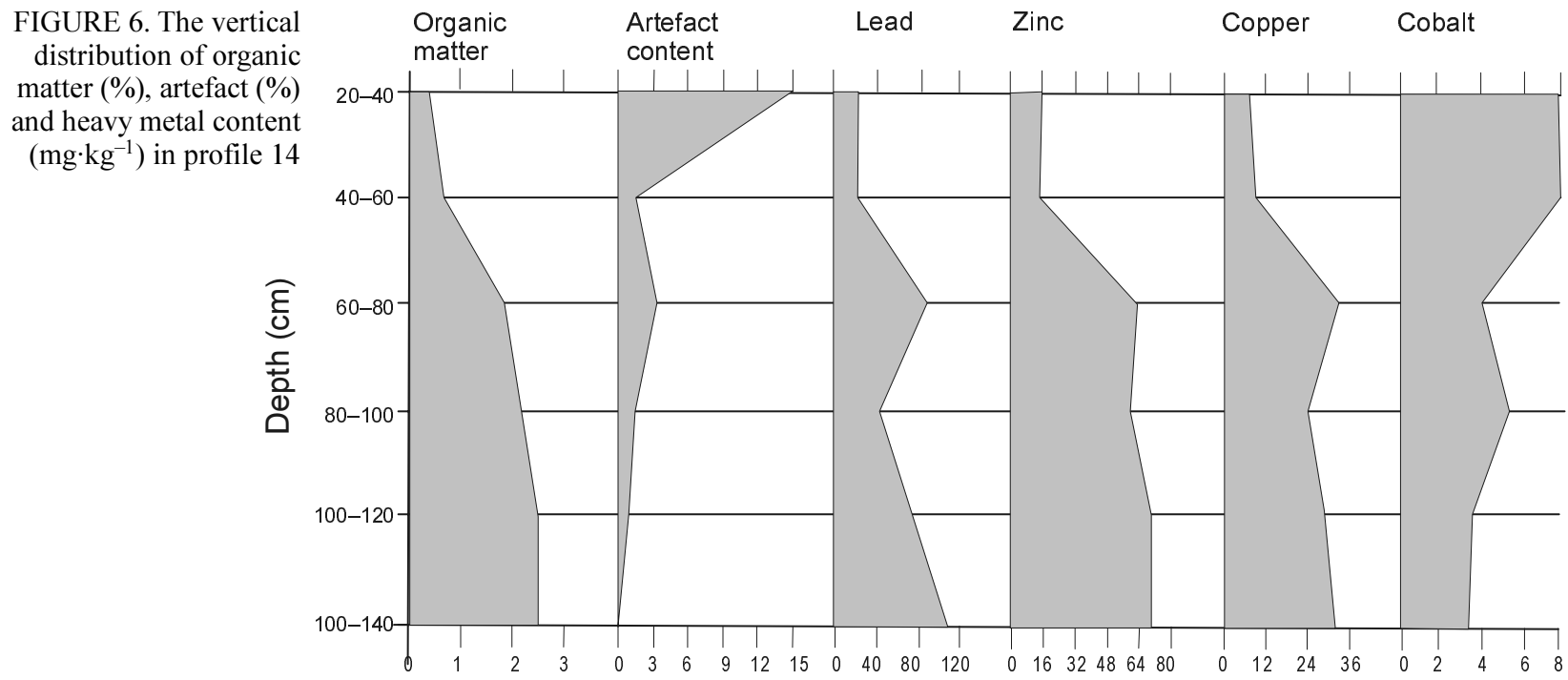

banking up might take place in this area in the past. The lead content exceeded the limit $\left(100 \mathrm{mg} \cdot \mathrm{kg}^{-1}\right)$ established in 6/2009 joint decree of the profile (Table 1).

monstrable in three profiles so the Ruptic qualifier was given. The heavy metal concentrations were measured above the Hungarian limit value in three profiles so the Toxic qualifier was used.

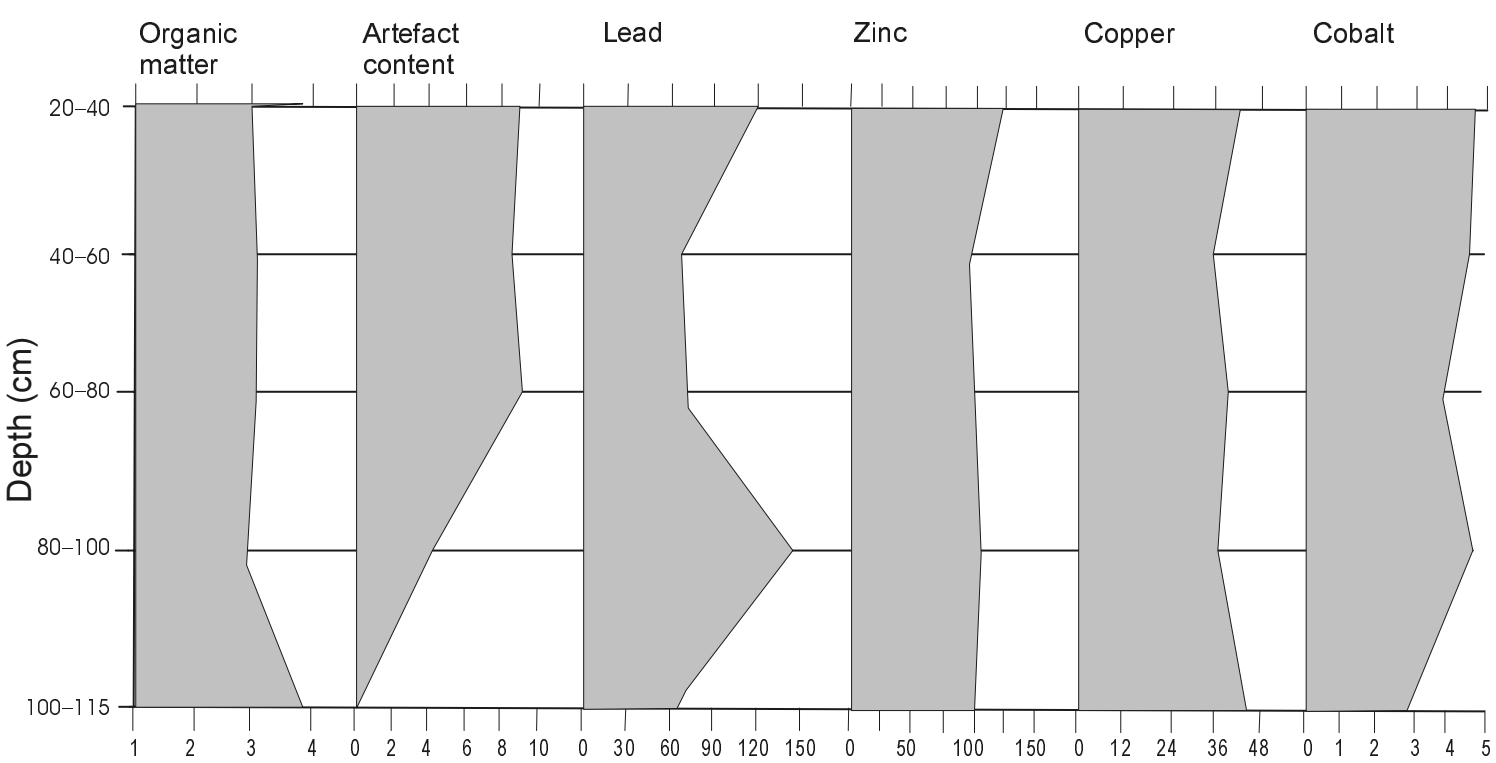

FIGURE 7. The vertical distribution of organic matter (\%), artefact (\%) and heavy metal content $\left(\mathrm{mg}^{\mathrm{k}} \mathrm{kg}^{-1}\right)$ in profile 21

\section{Classification of the soils studied}

The soil profiles studied were classified according to the WRB Soil Classification System (Table 3). We classified the examined profiles as Technosols ( 8 profiles), Phaeozems (2 profiles), and Arenosol (1 profile). All Technosols included an anthropogenic technic layer on the surface, therefore the Ekranic prefix qualifier was used in this case. The calcium carbonate content of the soils in the city centre of Debrecen in all profiles was $>2 \%$, so the Calcaric suffix qualifier was used. The lithological discontinuity was de-
TABLE 3. Soil classification

\begin{tabular}{ll}
\hline $\begin{array}{l}\text { Nr. of } \\
\text { profiles }\end{array}$ & WRB classification \\
\hline 7 & Ekranic Luvic Technosol (Calcaric) \\
8 & Luvic Phaeozem (Calcaric) \\
9 & Protic Arenosol (Calcaric) \\
10 & Ekranic Thaptomollic Luvic Technosol (Calcaric, Humic) \\
11 & Haplic Phaeozem (Calcaric, Endoarenic) \\
14 & Ekranic Technosol (Calcaric, Ruptic, Toxic, Arenic) \\
15 & Ekranic Technosol (Calcaric, Ruptic, Arenic) \\
19 & Ekranic Technosol (Calcaric, Ruptic, Endoarenic) \\
20 & Ekranic Technosol (Calcaric, Toxic, Epiarenic) \\
21 & Ekranic Thaptomollic Luvic Technosol (Calcaric, Toxic, Humic) \\
22 & Ekranic Technosol (Calcaric, Endoarenic) \\
\hline
\end{tabular}




\section{CONCLUSIONS}

- The soils of the Debrecen city centre are greatly affected by human activity. The original soil morphology cannot be identified in majority of the profiles, because of the accumulation of the cultural layers and the significant disruption.

- Diverse amounts of artefacts were found in each profile. The average artefact content of the soils of the city centre is $5.3 \%$ and the maximum artefact content is more than $16 \%$.

- The vertical distribution of the organic matter points to anthropogenic effect. Towards the deeper layers irregularly alternating layers of rich and poor humus content can be found. However, in the soils without hard covering layers the organic matter in the upper parts of profiles were the highest. In the case of the soils with the a between the hard and must be deleted covering layer, we found that generally the contents of organic matter increased with the increasing depth of soil.

- The investigated urban soils are moderately polluted by copper and lead, since in some samples a little bit higher values were measured than the limits established in Hungarian law.

- Heavy metal contents primarily correlate with the humus content and the particle size distribution. Moreover, in some cases we identified that higher amounts of metals are present in layers containing artefacts.

- The majority of the studied profiles were classified as Technosols. Some of them were classified as Phaeozems and Arenosols.

\section{ACKNOWLEDGMENTS}

The authors would like to express appreciation for the support of the TÁMOP-4.2.2/B-10/1-2010-0024.

\section{REFERENCES}

6/2009 (IV. 14.) Joint Decree of the Hungarian Ministries of Environment, Healthcare and Agriculture, respectively about the limit values and standard procedures to assess the pollution level, in order to protect the geological medium and ground-waters against pollution.

Bidló L., Szűcs P., Kámán O., Németh E., Horváth A., 2012. Soil conditions in Székesfehérvár. International Scientific Conference on Sustainable Development and Ecological Footprint, The Impact of Urbanization, Industrial and Agricultural Technologies on the Natural Environment: 1-6.

Charzyński P., Hulisz P., 2013. Soils forming on the buildings in Toruń [In] Technogenic soils of Poland (Charzyński P., Hulisz P., Bednarek R., Editors).Polisih Society of Soils Science, Toruń: 81-84.

Csorba P., 2008. Ecology pathway in Debrecen - Meridián Foundation, Debrecen: $44 \mathrm{pp}$.
Hargitai L., 1989. Investigation of humus-heavy metal connections and its environmental protection significance. Agrochemistry and Pedology 38(1-2): 155-160.

Horváth A., Szűcs P., Kámán O., Németh E., Bidló A., 2013. The examination of topsoils in Sopron and its area. Landscape Ecology 11(1): 1-10.

Howard J.L., Olszewska D., 2011. Pedogenesis, geochemical forms of heavy metals, and artifact weathering in an urban soil chronosequence, Detroit, Michigan. Environmental Pollution 159: 754-761.

Imperato M., Adamo P., Naimo D., Arienzo M., Stanzione D., Violante P., 2003. Spatial distribution of heavy metals in urban soils of Naples city (Italy). Environmental Pollution 124: 247-256.

IUSS Working Group WRB. 2007. World Reference Base for Soil Resources 2006, first update 2007. World Soil Resources Reports No. 103. FAO, Rome.

Kovács M., Nyári I., 1984. The heavy metal contents of the public places of Budapest. Agrochemistry and Pedology 33(3-4): 501-510.

Lark R.M., Scheib C., 2013. Land use and lead content in the soils of London. Geoderma 209-210: 65-74.

Li H.B., Yu S., Li G.L., Deng H., Luo X.S., 2011. Contamination and source differentiation of $\mathrm{Pb}$ in park soils along an urban-rural gradient in Shanghai. Environmental Pollution 159: 3536-3544.

Martonné E.K., 2008. Landscape Geography of Hungary. Debrecen, Kossuth University Press: 192 pp.

Puskás I., Farsang A., 2006. The evaluation of the parameters indicating the level of anthropogenic effects in urban soils. [In:] Kertész Á., Dövényi Z., Kocsis K., Editors). 2006. Third Hungarian Conference on Geography: book of abstracts. Budapest, Geographical Research Institute.

Puskás I., 2008. Soils of our cities: the complex evaluation and ranking of the soils in Szeged. University of Szeged, Szeged: $154 \mathrm{pp}$.

Shi G.T., Chen Z.L., Xu S.Y., Zhang J., Wang L., Bi C.J., Teng J.Y., 2008. Potentially toxic metal contamination of urban soils and roadside dust in Shanghai, China. Environmental Pollution 156: 251-260.

Szabó Gy., 2000. Geographical study of heavy metals in soils and plants in a sample area of the north hungarian mountains - Studia Geographica, University of Debrecen, Debrecen: $142 \mathrm{pp}$.

Szabó J., 1998. The effects of settlements. [In:] the effect of the society to the surface (anthropogenic geomorphology) (Borsy Z., Editor). General Natural Geography: $832 \mathrm{pp}$.

Szabó Sz., Posta J., Gosztonyi Gy., Mészáros I., Prokisch J., 2008. Heavy metal content of flood sediments and plants near the River Tisza. AGD Landscape and Environment 2: 120-131.

Szabó Sz., Posta J., 2008. The heavy metal content of the geological medium and the speed of the sedimentation in the floodplain [In:] Chapters from Geology dedicated for dr. Kozák Miklós (Püspöki Z., Editor). University of Debrecen, Debrecen: 85-90.

Szalai Z., Német T., 2008. The effects of the elemental regional pattern on the soils' chemical parameters) Hungarian Geographical Bulletin 57 (1-2): 135-146.

Szegedi S., 1999. Heavy metals in soils and plants of Debrecen of transportation origin, and its pedologic connections and city ecological effects PhD dissertation. Kossuth Lajos University, Department of Applied Landscape Geography, Debrecen: $138 \mathrm{pp}$.

Szegedi S., 2003. The characteristics of the heat island of Debrecen - Chapters from Environment Protection - Fort the 60 . birthday of Dr. Kerényi Attila, Debrecen: 383-389.

website 1: http://www.geography.hu/geographer/geczi_robert/ GR_varosi_talajok.pdf

website 2: http://portal.debrecen.hu/upload/File/Gazdasag/ koncepciok/kornyezetvedelmi\%20program\%20.pdf

Received: October 12, 2013

Accepted: March 11, 2014 